\title{
LAST LIVING ECHOES OF THE NATICK
}

\section{By J. DYNELEY PRINCE}

In his interesting Introduction to Trumbull's Natick Dictionary (pp. xii-xiii), the Reverend Edward Everett Hale states that the native community of Mashpee Indians, occupying the town of Mashpee on Cape Cod, has now lost every trace of the old Indian customs and that at the present time " no word of the language of their race is spoken." In short, that not one of the Mashpee Indians has "any further knowledge of it [the language] than does any other New Englander."

Mr Frank G. Speck, at my instigation, visited the community of Mashpee from March 28 until April I, 1907, and, somewhat to my surprise, has returned bringing a vocabulary of twenty-nine distinctly Natick words which he, with great difficulty, succeeded in collecting from five aged persons, viz, Roxie Nye ( 85 years), George Okrey = Oakley? (90 years), Lydia Keeter (88 years), Rebecca Amos, and John Booker, an old man of negro blood. Mr Speck's most searching questionings among some fifteen families of the Indian town failed to bring to light more than is herein given, and it is extremely doubtful whether anything further is now known of the early language.

This community at Mashpee is about all that remains of the eastern Massachusetts and Cape Cod tribes and clans, although there is still an Indian remnant at Gay Head on Martha's Vineyard which, however, consists probably more of Narragansett stock than of the Natick strain. Of the total number of Indians at Mashpee, about two-thirds exhibit markedly Indian characteristics. Mr Speck states, in fact, that many of these people look almost like fullblood Algonquins, although there is a strong admixture of negro blood which in the end, he thinks, is bound to predominate. There can be no doubt, however, that some of the Mashpee family-names are distinctly of Indian derivation, viz.: Pognet, Attaquin, Queppish, Webquish, Squib, Keeter, Popnonet, and perhaps also Toby. 
Dr Hale's statement that the Natick has not been spoken for a long period is literally correct, as there is no one now living, who, for example, like Mrs Fielding of the Pequot-Mohegan settlement at Mohegan, Connecticut, ${ }^{1}$ can talk Indian consecutively; but, on the other hand, there still remains in the memories of some of the older people much that is interesting concerning the ancient customs, and, contrary to Dr Hale's statement, at least twenty-nine isolated words of the old speech.

The town of Mashpee, which, by the bye, is self-governing and a model of its kind, is situated at the foot of Mashpee lake, a site which was an ancient camping-place of the Indians. This is evidenced by the frequent discovery of stone implements in the fields bordering the Mashpee river, which is the outlet of the lake. The oldest people still remember the original Indian houses (still called zeigizwân) which they say were of two sorts. One form of house was constructed of poles, leaned together and covered with cedar bark, leaving a smoke-vent at the top, and an inverted $V$-shaped opening at the bottom for ingress and egress. This style of lodge was seldom more than ten feet in diameter. The second kind of house, which was more commodious, was made of hickory saplings arched and bound in a complex dome-shaped framework. The top and sides were covered with bunches of tightly bound grass. This house also had a smoke-vent in the roof. Around the sides of this larger and more permanent lodge stood beds of sapling framework, supported by crotched sticks. The fireplace was in the center, and near it lay a green stick ( $k \dot{a}$ nititänk), about three feet long and supplied with a crook at the end, with which to stir the ashes and embers. Scoops, ladles, variously shaped wooden bowls, twilled baskets, and mats woven of corn-husks constituted the chief household appurtenances remembered by the old people to-day.

The Indians also used large back-baskets with narrow necks, having a bale running outside and across the bottom with a widened portion at the end where it passed across the forehead or chest of the carrier. Several types of these back-baskets are made and in

${ }^{1}$ See Prince and Speck in American Anthrofologist, v, 193-21 2 ; v1, 18-45, 469476. On the remnants of the Mohican dialect in Connecticut, see Prince and Speck in Proc. Amer. Philus. Sicc., 1903, 346-352. 
use to-day at Mashpee. Furthermore, the older people remember the wooden mortars, hollowed from logs with the bark left on, and also the pestles made of hickory. They also recall certain long smooth stones of very ancient origin which were used as pestles.

Corn was their chief staple and was prepared in various ways, sometimes pounded into flour-meal (nokik) and boiled into porridge $(\operatorname{san} p)$ or else cooked whole with beans (sikitüc $=$ "succatash"). Game was sometimes cooked by suspending it over the fire on a thong ; it was then kept turning by twisting and untwisting the thong.

Their canoes were made of hollowed white-pine trunks. If the trees were not large enough, two such trunks were shaped and fastened together lengthwise catamaran-fashion. In these canoes they went night-fishing (wïkwâsinn), attracting the fish within clubrange or bow-shot by means of pine-knot torches fastened at the prow.

The only mention the present Mashpee authorities make of former religious beliefs is that the spirits of the departed (ticipai) frequently appeared in the paths of the living, and that such ghosts required propitiation before they could be induced to clear the way. The ancient Indians, they say, were always telling of meeting spirits on their journeys. Consequently, a religious practice grew out of this belief, viz, that of erecting great square flat-topped lodges covered with brush at certain points along their accustomed roads or paths. At these the Indians used to stop and deposit some piece of property or food, or else pour out a libation of whisky. They also held religious meetings and carousals in these lodges. Such Mashpee of to-day as are superstitiously inclined still observe the custom of throwing a twig or branch upon the rotting framework, or on the former sites of these spirit-lodges, whenever they pass by.

In noting the following Mashpee-Natick words and sentences, $\mathrm{Mr}$ Speck has observed the usual system, viz: $\hat{a}$, closed like $a$ in 'ball'; $\ddot{a}$, like $a$ in 'cat'; $u$, like $u$ in 'put'; $\dot{a}$, like $u$ in 'but'; $\ddot{i}$, like $i$ in ' pin'; $\tilde{n}=$ palatal nasal in $n g$; $t c$, like $c h$ in 'church'; $c$, like $s / 2$ in 'she'.

\section{Glossary}

Atuk 'deer' $=$ N.' ahtuk; Narr. attuck; Pass. attuk.

iN. = Natick; Narr. = Narragansett ; Aben. $=$ Canadian Abenaki ; Pen. == Pen. obscot; Pass. =: Passamaquoddy. 
Häncâ 'come in!=N. howvan, interr. pron. 'who?' + exclam. chuh 'ho!' See Trumbull, Natick Dictionary, 277. Hāncâ, therefore, means lit. 'who ho?'

Kanutänk 'fire-poker; long wooden crooked stick' $=$ N. kenuhtugq 'sharp wooden pin' (Trumbull, 33).

$K z \in \hat{a}^{\prime} h \hat{a g}$ 'clams'. Evidently a corruption of Narr. poquauhock 'clams.' 'This word also existed in the Long Island dialect. Cf. the place-name Quogue.

$M \ddot{a} c \ddot{a}$ 'nïk' rabbits' ; apparently not a plural in $-k$. This must be the same word as mishanneke (Narr.) and N. mishánnek 'squirrel.' I derive it from the same stem as in N. nehnekinnau ' he scratches.' The question arises, whether Mr Speck's informant was correct in applying it to a rabbit, for which Trumbull gives no equivalent. If it means 'scratcher' $=$ 'digger', it would apply well to the digging rodent.

Nókïk 'dried pounded corn' = N. nuhkik. A most interesting survival. See Prince in Proc. Amer. Philos. Soc., I903, $350=$ rutig in the corrupt Mohican dialect still surviving in the mouth of James Harris of Kent, Litchfield Co., Conn. = Peq. yokeg.

$N u t$ 'fire' $=\mathrm{N}$. zatau, nuteau; also Narr. note and yote. Cf. the Peq. wiyut 'fire.' Note the interchange of N. $n$ and Peq. $y$.

Papus and Pâmpus 'baby' of course = Narr. papoos; Stiles puppous; N. papeases. Evidently a reduplication of the root pea 'little' + the diminutive suffix $-s$, sis, seen also in Aben. pizsessit. 'The nasalized form pampus is peculiar perhaps to the late Mashpee dialect.

Sämp ' dried pounded corn' $=$ Narr. nasáump ' meal-soup' $=\mathrm{N}$. saupaen 'soft substance.' Cf. the old Dutch loan form suppaen, pron. suppawn and still used in northern New Jersey for corn-soup.

Skätcimi 'how do you do?' Evidently a half remembered form containing the root of N. kesuk 'day.' It probably meant ' good-day.'

Skétciyan 'how do you do?' 'The same as the above, only containing the $2 \mathrm{~d}$ pers. participial ending -an.

Sûkżtäc 'corn' and 'bean soup porridge; boiled corn.' A well known New England word. It is the Narr. "m'sickquatash 'something beaten up.' Cf. suquttahham ' he beats it to pieces.'

Tâ'bät 'thank you' = N. tabuttantum ' he is thankful.' Cf. Peq. tahbut ne 'thank you.' It is from tapi ' enough' + the ending -antum, indicating a mental condition. Tấbat in Mashpee is a shorter form = $t_{a f i}+t$ of the $3^{\mathrm{d}}$ pers. Note the Mashpee sentence tâbat enhi'mat ankitci 'thank you very much.' This seems to contain a verb in the rst pers., as indicated by the prefix $e n$ in $e n h \vec{t}^{\prime} n \dot{a}$. I regard $e n h \ddot{t}^{\prime} m a \dot{t} t$ as a corrup- 
tion of N. enhcttamun 'I speak' or 'say it' (see Trumbull, 27). $A_{n-1}$ kittci is $e n+$ kutci = kehche 'chief' $=$ ' my chief,' viz, 'thanks I speak it my chief.' Tâbat enmahitcnäk ' thank you, master' cuntains tâbat + the Ist pers. of a corrupted form of N. magze 'give, offer.' I believe the ending $-n . i k$ in the form enmahitcnak is the echo of a second person plural $=$ 'I offer it to you.'

Tấ $\hat{a}^{\prime}$ cant 'child' is probably the survival of an original word with a wrong meaning applied to it. In N. tahshe, tohsu means ' how much?' Perhaps an error on the part of Mr Speck's informant.

$T a^{\prime}$ 'mpam 'line to hold a back-basket,' which was carried by a strap or line resting against the forehead or chest. This is the same root as in Aben. madomba, and appears in Canadian English in the compound tump-line.

Titcizvañk 'dish-cloth.' Probably from Eng. dish + the ending wank (?).

Tukkkim 'basket material ; white-oak splints' $=$ N. zoutuhq, zeruttuk 'bough, branch' (Trumbull, 228).

$T c i^{\prime} n k c u$ 'daughter' undoubtedly $=\mathrm{N}$. kehche-nunsqua ' large girl ; grown girl ' and not specifically 'daughter.'

Tcipai 'spirit' appears in N. chepi-ohke 'spirit-land.' Cf. Peq. jibaii-ohke. Tcipai survives also in tcipai wainkkcas 'spirit-fox,' referring to the phosphorescent glow of rotten wood. As a sign of death to the beholder, this is known in Cape Cod folk-lore as 'fox-fire.'

Wâmp'devil' (?) in a proper name must = the ending -zeomp as seen in N. mugqwomp 'chief,' from which is derived the American slang mugzump. This wamp, womp = Aben. -ômba (Pen. $-\hat{a} b e$ ) in Aben. alnômba 'Indian.' Cf. Pass. skit-ap 'man'; Delaware len-âpe 'man.'

Wiankcis ' $\mathrm{fox}$ ' $=\mathrm{N}$. wonkqussis, wonksis 'fox.'

Wi'gizeâm 'house' is a mixture of the common English wigwam, from Aben. wigzwâm and the older Natick wekuzomut ' in his house'; lit. 'where he lives.' Trumbull gives N. zeetu as the short form ' his house.' In Aben., Pass., etc. the stem zoig, wik = 'live, dwell.'

Wikwâsin 'night fishing by torch-light' contains the N. wequai 'light,' seen in Eliot's Bible, Gen. I, 4. Cf. Narr. wequaii.

Witcäk 'woodchuçk' nust be a combination of English woodchuck which is originally Algonquian + N. ockqutchaun (Trumbull, 277).

There can be no doubt that the words herein given which have lingered in the memories of these few old Indian descendants are original Natick, in some cases altered from the primitive speech, 
but still surprisingly recognizable. Sämp and sükïtäc, of course, might be survivals common among the English New Englanders. One very important point seems to be brought out by these tattered shreds of a long dead language. That is, that the first personal verbal prefix, which is given by Eliot as ne-, was pronounced, at least in the Eastern dialect, as $a n$, with the inherent sound of the n, rather than as $n$ followed by a vowel (cf. s. v. tâbat).

The thanks of all Americanists who are interested in the study of Algonquian are due to $\mathrm{Mr}$ Speck, who, by his trained skill in eliciting information from unintelligent and aged persons, has succeeded in rescuing from oblivion these last echoes of a forgotten speech which once played a notable part in the history of this country.

Columbia University, New YORK CITY. 